\title{
Terrimonas rubra sp. nov., isolated from a polluted farmland soil and emended description of the genus Terrimonas
}

\author{
Correspondence \\ Xing Huang \\ huangxing@njau.edu.cn \\ Yu Zhou \\ microbes@yahoo.cn
}

\author{
Jing Zhang, ${ }^{1}$ Tao Gu, ${ }^{1}$ Yu Zhou, ${ }^{2,3}$ Jie He, ${ }^{3}$ Liu-Oiang Zheng, ${ }^{3}$ \\ Wen-Jun Li, ${ }^{3}$ Xing Huang ${ }^{1}$ and Shun-Peng $\mathrm{Li}^{1}$
}

\begin{abstract}
${ }^{1}$ Key Laboratory for Microbiological Engineering of Agricultural Environment, Ministry of Agriculture, College of Life Sciences, Nanjing Agricultural University, Nanjing, Jiangsu 210095, PR China

${ }^{2}$ State Key Laboratory Breeding Base for Zhejiang Sustainable Plant Pest Control, Agricultural Ministry Key Laboratory for Pesticide Residue Detection, Zhejiang Province Key Laboratory for Food Safety, and Institute of Quality and Standard for Agro-products, Zhejiang Academy of Agricultural Sciences, Hangzhou, Zhejiang, 310021, PR China

${ }^{3}$ The Key Laboratory of Microbial Diversity in Southwest China, Ministry of Education and Laboratory for Conservation and Utilization of Bio-Resources, Yunnan Institute of Microbiology, Yunnan University, Kunming, 650091, PR China
\end{abstract}

\begin{abstract}
A salmon-red-pigmented bacterial strain, designated $M-8^{\top}$, was isolated from a polluted farmland soil sample in China and was characterized in a taxonomic study using a polyphasic approach. Strain $\mathrm{M}-8^{\top}$ was Gram-stain-negative, rod-shaped, non-motile and non-spore-forming. Growth occurred at $20-37{ }^{\circ} \mathrm{C}$, at $\mathrm{pH} 5.0-10.0$ and with 0-2\% (w/v) $\mathrm{NaCl}$. Phylogenetic analysis based on 16S rRNA gene sequences showed that strain $\mathrm{M}-8^{\top}$ belonged to the genus Terrimonas.16S rRNA gene sequence similarity values between strain $M-8^{\top}$ and the type strains of the three recognized species of the genus Terrimonas, Terrimonas ferruginea KACC $11310^{\top}$, Terrimonas aquatica LMG $24825^{\top}$ and Terrimonas lutea KACC $13047^{\top}$, were 97.1, 96.3 and 95.3\%, respectively. The predominant respiratory quinone was menaquinone-7 (MK-7) and the major fatty acids were iso- $\mathrm{C}_{15: 0}$, iso- $\mathrm{C}_{17: 0} 3-\mathrm{OH}$ and summed feature 3 (comprising $\mathrm{C}_{16: 1} \omega 7 \mathrm{c}$ and/or $\left.\mathrm{C}_{16: 1} \omega 6 \mathrm{c}\right)$. The DNA G+C content of strain $\mathrm{M}-8^{\top}$ was $47.0 \mathrm{~mol} \%$. On the basis of genotypic and phenotypic data, strain $\mathrm{M}-8^{\top}$ is considered to represent a novel species of the genus Terrimonas, for which the name Terrimonas rubra sp. nov. is proposed. The type strain is $M-8^{\top}$ $\left(=\mathrm{CCTCC}\right.$ AB $\left.2010401^{\top}=\mathrm{KCTC} 23299^{\top}\right)$. An emended description of the genus Terrimonas is also presented.
\end{abstract}

The genus Terrimonas was proposed by Xie \& Yokota (2006) with Terrimonas ferruginea as the type species. At the time of writing, the genus Terrimonas comprised three recognized species: Terrimonas aquatica, Terrimonas lutea and T. ferruginea ( $T$. ferruginea was previously described as [Flavobacterium] ferrugineum) (Sheu et al., 2010; Xie \& Yokota, 2006). Members of the genus Terrimonas are generally characterized as strictly aerobic, Gram-negative, non-motile, non-gliding and non-filamentous bacteria that are oxidase-positive and weakly catalase-positive. These bacteria usually contain iso- $\mathrm{C}_{15: 0}$, iso- $\mathrm{C}_{15: 1} \mathrm{G}$, iso- $\mathrm{C}_{17: 0} 3-$ $\mathrm{OH}$ and summed feature 3 as major fatty acids, menaquinone-7 (MK-7) as the predominant respiratory quinone and have DNA G + C contents of 47.0-48.9 mol\%.

The GenBank/EMBL/DDBJ accession number for the $16 \mathrm{~S}$ rRNA gene sequence of strain $M-8^{\top}$ is JF803808.

A supplementary table is available with the online version of this paper.
During a project to investigate bacterial diversity from an imazethapyr (a weedkiller)-polluted farmland soil in Shandong Province, China, a salmon-red-pigmented bacterial strain, designated $\mathrm{M}-\mathrm{8}^{\mathrm{T}}$, was isolated and studied using a polyphasic taxonomic approach. Initial $16 \mathrm{~S}$ rRNA gene sequence analysis indicated that strain $\mathrm{M}-8^{\mathrm{T}}$ was related most closely to $T$. ferruginea KACC $11310^{\mathrm{T}}$, T. aquatica LMG $24825^{\mathrm{T}}$ and T. lutea KACC $13047^{\mathrm{T}}$ (97.1, 96.3 and $95.3 \%$ similarity, respectively). Strain $\mathrm{M}-8^{\mathrm{T}}$ clustered closely with the above type strains, and the four strains formed a separate phylogenetic branch within the family Chitinophagaceae. To determine the taxonomic and phylogenetic position of strain $\mathrm{M}-8^{\mathrm{T}}$, T. ferruginea KACC $11310^{\mathrm{T}}, T$. aquatica LMG $24825^{\mathrm{T}}$ and T. lutea KACC $13047^{\mathrm{T}}$ were selected for comparison of morphological, physiological, biochemical and chemotaxonomic characteristics; and DNA-DNA hybridizations were also performed between strain $M-8^{\mathrm{T}}$ and its two closest phylogenetic neighbours 
(T. ferruginea KACC $11310^{\mathrm{T}}$ and T. aquatica LMG $24825^{\mathrm{T}}$ ). Data from the present study indicate that strain $\mathrm{M}-8^{\mathrm{T}}$ represents a novel species of the genus Terrimonas.

Strain $\mathrm{M}-8^{\mathrm{T}}$ was isolated from a polluted soil sample after plating dilutions (distilled water) onto R2A agar and incubation at $30{ }^{\circ} \mathrm{C}$ for 3 days. Subcultivation was performed on $\mathrm{R} 2 \mathrm{~A}$ agar medium at $30{ }^{\circ} \mathrm{C}$ for $48-72 \mathrm{~h}$. The pure culture of strain $\mathrm{M}-8^{\mathrm{T}}$ was preserved at $-80{ }^{\circ} \mathrm{C}$ in $\mathrm{R} 2 \mathrm{~A}$ broth with $20 \%(\mathrm{v} / \mathrm{v})$ glycerol. T. ferruginea KACC $11310^{\mathrm{T}}$ and T. lutea KACC $13047^{\mathrm{T}}$ were obtained from the Korean Agricultural Culture Collection (KACC) and T. aquatica LMG $24825^{\mathrm{T}}$ was obtained from the BCCM/LMG Bacteria Collection. The type strains of the three recognized Terrimonas species were selected as reference strains for DNADNA hybridization experiments and for chemotaxonomic and physiological characterization.

Cell morphology was determined by transmission electron microscopy (H-7650; Hitachi). Gram staining was performed following the method described by Beveridge et al. (2007). Catalase activity was determined by assessing bubble production in $3.0 \%(\mathrm{w} / \mathrm{v}) \mathrm{H}_{2} \mathrm{O}_{2}$. Oxidase activity was tested by using oxidase reagent (bioMérieux) according to the manufacturer's instructions. The presence of flexirubin-type pigments was detected by using $20 \% \mathrm{KOH}$ (Fautz \& Reichenbach, 1980). The $\mathrm{pH}$ range for growth was determined by measuring the optical density (wavelength $600 \mathrm{~nm}$ ) of R2A broth adjusted to $\mathrm{pH} 4-10$ (at intervals of $1.0 \mathrm{pH}$ unit) by using appropriate biological buffers (Chung et al., 1995). The temperature range for growth was determined on R2A agar at 4, 10, 15, 20, 25, 30, 32, 37, 40 and $45^{\circ} \mathrm{C}$. Tolerance to $\mathrm{NaCl}$ was tested in modified R2A broth lacking $\mathrm{NaCl}$ and with $0.5 \%$ and $1.0-5.0 \%$ (w/ v) $\mathrm{NaCl}$ (intervals of $1.0 \%$ ). Antibiotic susceptibility was examined by placing different antibiotic discs on R2A agar as described by Zhou et al. (2007). The antibiotic discs (Oxoid) tested were: ampicillin $(10 \mu \mathrm{g})$, chloramphenicol $(30 \mu \mathrm{g})$, gentamicin $(10 \mu \mathrm{g})$, kanamycin $(30 \mu \mathrm{g})$, nalidixic acid $(30 \mu \mathrm{g})$, novobiocin $(5 \mu \mathrm{g})$, rifampicin $(5 \mu \mathrm{g})$, penicillin $\mathrm{G}(1 \mu \mathrm{g})$, streptomycin $(10 \mu \mathrm{g})$, trimethoprim $(5 \mu \mathrm{g})$ and tetracycline $(30 \mu \mathrm{g})$. Additional biochemical tests were performed by using API ZYM and API 20NE kits (bioMérieux) and carbon source utilization was evaluated by using the Biolog GN2 microplate (Biolog) according to the manufacturers' instructions. Comparative phenotypic characteristics between strain $\mathrm{M}-8^{\mathrm{T}}$ and the type strains of recognized Terrimonas species are given in Table 1 and Table S1 (available in IJSEM Online). The detailed

Table 1. Differential phenotypic characteristics between strain $M-8^{\top}$ and the type strains of species of the genus Terrimonas

Strains: 1 , M-8 $8^{\mathrm{T}} ; 2$, T. ferruginea KACC $11310^{\mathrm{T}} ; 3$, T. aquatica LMG $24825^{\mathrm{T}}$; 4, T. lutea KACC $13047^{\mathrm{T}}$. All data were obtained from the present study. +, Positive; -, negative; $(+)$, weakly positive.

\begin{tabular}{|c|c|c|c|c|}
\hline Characteristic & 1 & 2 & 3 & 4 \\
\hline Colony pigmentation & Salmon red & Salmon red & Yellowish-orange & Yellow \\
\hline Growth temperature range $\left({ }^{\circ} \mathrm{C}\right)$ & $20-37$ & $10-37$ & $10-37$ & $10-37$ \\
\hline Growth with $2 \% \mathrm{NaCl}$ & + & + & - & - \\
\hline \multicolumn{5}{|l|}{ Enzyme activities } \\
\hline Trypsinase & + & - & - & + \\
\hline$\alpha$-Chymotrypsin & + & - & - & + \\
\hline$\alpha$-Galactosidase & + & - & + & + \\
\hline$\beta$-Galactosidase & - & - & + & + \\
\hline$\beta$-Glucuronidase & - & - & $(+)$ & - \\
\hline$\alpha$-Glucosidase & + & $(+)$ & + & + \\
\hline$\beta$-Glucosidase & - & $(+)$ & + & + \\
\hline$\alpha$-Mannosidase & - & $(+)$ & $(+)$ & + \\
\hline$\beta$-Fucosidase & + & - & + & $(+)$ \\
\hline \multicolumn{5}{|l|}{ Assimilation of: } \\
\hline Glucose & + & - & + & - \\
\hline Arabinose & + & $(+)$ & + & - \\
\hline Mannose & + & - & + & $(+)$ \\
\hline $\mathrm{N}$-Acetylglucosamine & + & $(+)$ & + & - \\
\hline Maltose & + & $(+)$ & + & - \\
\hline \multicolumn{5}{|l|}{ Sensitivity to: } \\
\hline Chloramphenicol & + & + & - & + \\
\hline Gentamicin & - & - & + & + \\
\hline Nalidixic acid & + & + & + & - \\
\hline Roxithromycin & + & - & - & - \\
\hline Streptomycin & - & + & + & + \\
\hline Vancomycin & + & + & - & + \\
\hline
\end{tabular}


phenotypic characteristics of strain $\mathrm{M}-8^{\mathrm{T}}$ are given in the species description below.

Genomic DNA was prepared for 16S rRNA gene amplification and DNA G $+\mathrm{C}$ content and DNA-DNA hybridization tests according to the method described by Marmur (1961). Bacterial universal primer set $27 \mathrm{~F}$ and $1492 \mathrm{R}$ was selected for PCR amplification of the 16S rRNA gene (Lane, 1991). PCR amplification of the 16S rRNA gene sequence was performed as described by Li et al. (2007). The $16 \mathrm{~S}$ rRNA gene sequence was manually aligned with reference sequences retrieved from the GenBank database following BLAST searches. A phylogenetic tree was constructed by using the MEGA version 4.0 software package (Tamura et al., 2007) after multiple alignment of the sequence data by CLUSTAL_x (Thompson et al., 1997). The corrected evolutionary distance was calculated according to Kimura's two-parameter model (Kimura, 1980, 1983) and clustering was based on the neighbour-joining and maximum-parsimony methods. Bootstrap analysis was used to evaluate the tree topology by performing 1000 resamplings (Felsenstein, 1985). The almost-complete 16S rRNA gene sequence (1418 nt) of strain $\mathrm{M}-8^{\mathrm{T}}$ was obtained in the present study. 16S rRNA gene sequence analysis indicated that strain $\mathrm{M}-8^{\mathrm{T}}$ belongs to the genus Terrimonas and was most closely related to $T$. ferruginea KACC $11310^{\mathrm{T}}$, T. aquatica LMG $24825^{\mathrm{T}}$ and $T$. lutea KACC $13047^{\mathrm{T}}$. The four strains formed a distinct phylogenetic branch within the family Chitinophagaceae (Fig. 1).

DNA-DNA hybridization experiments were performed to further clarify the level of relatedness between strain $\mathrm{M}-8^{\mathrm{T}}$ and T. ferruginea KACC $11310^{\mathrm{T}}$ and T. aquatica LMG $24825^{\mathrm{T}}$ (Stackebrandt \& Goebel, 1994). DNA-DNA hybridization experiments were carried out according to the method described by Ezaki et al. (1989). Levels of DNADNA relatedness between strain $\mathrm{M}-8^{\mathrm{T}}$ and $T$. ferruginea KACC $11310^{\mathrm{T}}$ and T. aquatica LMG $24825^{\mathrm{T}}$ were 54.3 and $23.0 \%$, respectively, which were significantly lower than the threshold value of $70 \%$ commonly accepted for definition of a novel bacterial species (Stackebrandt \& Goebel, 1994).

Analysis of cellular fatty acids was performed as described by Sasser (1990) by using the Microbial Identification System (MIDI, Sherlock Version 6.1) and TSBA6 database. Bacterial biomass collected for analysis of cellular fatty acids was cultivated at $30{ }^{\circ} \mathrm{C}$ for 2 days on R2A agar plates and the cells were harvested from the third quadrant of the quadrant-streaked plate. The fatty acid profile of strain M$8^{T}$ was similar to those of the type strains of the three recognized species of the genus Terrimonas determined with the same cultivation and analysis conditions in the present study (Table 2). The major fatty acids of strain $\mathrm{M}-8^{\mathrm{T}}$ were iso- $\mathrm{C}_{15: 0}$, iso- $\mathrm{C}_{17: 0} 3-\mathrm{OH}$ and summed feature 3

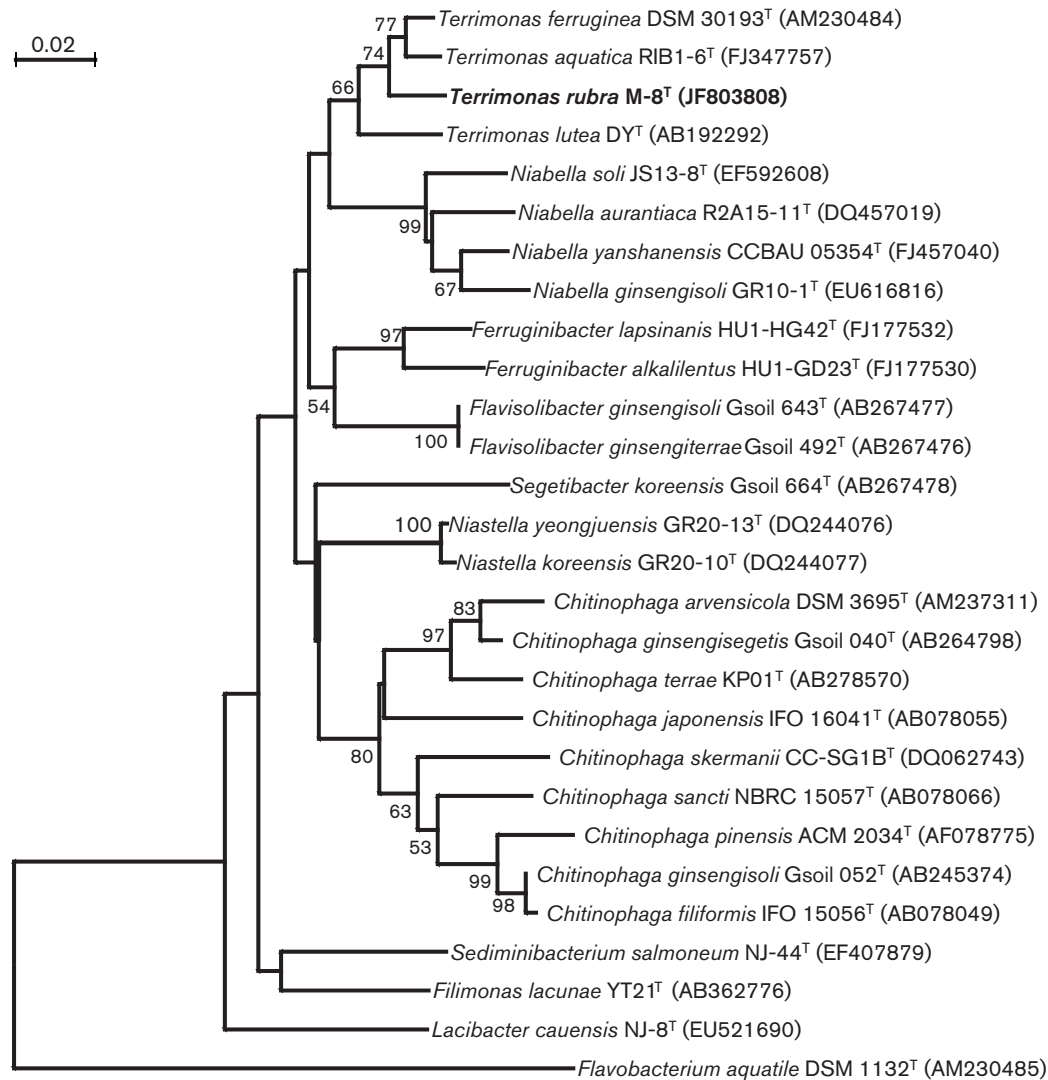

Fig. 1. Neighbour-joining phylogenetic tree based on 16S rRNA gene sequences showing the relationship between strain $M-8^{\top}$ and related taxa in the family Chitinophagaceae. Bootstrap values (expressed as percentages of 1000 replications) $>50 \%$ are shown at branch points. Flavobacterium aquatile DSM $1132^{\top}$ was used as an outgroup. Bar, 0.02 substitutions per nucleotide position. 
Table 2. Cellular fatty acid profiles of strain $M-8^{\top}$ and the type strains of recognized species of the genus Terrimonas

Strains: $1, \mathrm{M}-8^{\mathrm{T}} ; 2$, T. ferruginea KACC $11310^{\mathrm{T}} ; 3$, T. aquatica LMG $24825^{\mathrm{T}}$; 4, T. lutea KACC $13047^{\mathrm{T}}$. Values are percentages of the total fatty acids. All data were obtained from the present study under the same test conditions.

\begin{tabular}{|c|c|c|c|c|}
\hline Fatty acid & 1 & 2 & 3 & 4 \\
\hline $\mathrm{C}_{16: 0}$ & 1.7 & 2.1 & 1.2 & 1.5 \\
\hline iso- $\mathrm{C}_{15: 0}$ & 36.7 & 44.8 & 43.5 & 36.9 \\
\hline iso- $\mathrm{C}_{15: 1}$ & 8.4 & 19.8 & 15.1 & 18.1 \\
\hline iso- $\mathrm{C}_{15: 0} 3-\mathrm{OH}$ & 2.9 & 1.8 & 4.5 & 2.6 \\
\hline $\mathrm{C}_{15: 0} 2-\mathrm{OH}$ & 1.3 & 0.3 & 0.8 & 1.4 \\
\hline $\mathrm{C}_{15: 0} 3-\mathrm{OH}$ & 1.1 & 0.1 & 0.4 & 1.1 \\
\hline $\mathrm{C}_{16: 0} 3-\mathrm{OH}$ & 4.3 & 2.1 & 2.3 & 2.8 \\
\hline $\mathrm{C}_{17: 0} 3-\mathrm{OH}$ & 0.7 & 0.2 & 0.4 & 1.1 \\
\hline iso- $\mathrm{C}_{17: 0} 3-\mathrm{OH}$ & 12.4 & 14.2 & 15.3 & 13.1 \\
\hline Summed feature $3^{*}$ & 25.1 & 9.0 & 11.8 & 16.0 \\
\hline
\end{tabular}

* Summed features are fatty acids that cannot be separated by GC with the Microbial Identification System (Microbial ID) software. Summed feature 3 comprised $\mathrm{C}_{16: 1} \omega 6 c$ and/or $\mathrm{C}_{16: 1} \omega 7 c$.

(comprising $\mathrm{C}_{16: 1} \omega 7 c$ and/or $\mathrm{C}_{16: 1} \omega 6 c$ ). Respiratory quinones were extracted from lyophilized cells and the extracts were purified and analysed by HPLC according to the method of Collins (1985). The predominant respiratory quinone of strain $\mathrm{M}-8^{\mathrm{T}}$ was menaquinone-7 (MK-7), which is consistent with members of the genus Terrimonas. The DNA $\mathrm{G}+\mathrm{C}$ content was determined by reversed-phase HPLC according to Mesbah et al. (1989). The DNA G+C content of strain $\mathrm{M}-8^{\mathrm{T}}$ was $47.0 \mathrm{~mol} \%$, consistent with data for recognized Terrimonas species (47.0-48.9 mol\%).

Phylogenetic analysis and chemotaxonomic characteristics (major fatty acids, predominant respiratory quinone, DNA $\mathrm{G}+\mathrm{C}$ content) unequivocally supported placement of strain $\mathrm{M}-8^{\mathrm{T}}$ within the genus Terrimonas. However, differences in phenotypic characteristics (Tables 1 and S1) between strain $\mathrm{M}-8^{\mathrm{T}}$ and the type strains of the three species of the genus Terrimonas suggested that strain $\mathrm{M}-8^{\mathrm{T}}$ cannot be assigned to any recognized species of this genus. Furthermore, strain M$8^{\mathrm{T}}$ could be differentiated from recognized Terrimonas species based on differences in fatty acid composition (Table 2). Morphological, physiological and chemotaxonomic characteristics together with DNA-DNA hybridization results thus supported the suggestion that strain $\mathrm{M}-8^{\mathrm{T}}$ represents a novel species of the genus Terrimonas, for which the name Terrimonas rubra sp. nov. is proposed.

In the present study, levels of iso- $\mathrm{C}_{15: 1} \mathrm{G}$ in strain $\mathrm{M}-8^{\mathrm{T}}$ $(8.4 \%)$ and summed feature 3 in $T$. ferruginea KACC $11310^{\mathrm{T}}(9.0 \%)$ were lower than $10 \%$, and thus should not be listed as major fatty acid components for the genus Terrimonas. Gliding ability was observed for strain $\mathrm{M}-8^{\mathrm{T}}$, but not for T. ferruginea, T. aquatica or T. lutea. Strain $\mathrm{M}-8^{\mathrm{T}}$ was strictly positive for catalase activity. Additionally, growth of strain $\mathrm{M}-8^{\mathrm{T}}$ was observed in the presence of $2 \%$ $(\mathrm{w} / \mathrm{v}) \mathrm{NaCl}$, and nitrate was not reduced; characteristics not previously described for the genus Terrimonas. Therefore, an emended description of the genus Terrimonas is proposed.

\section{Emended description of the genus Terrimonas}

Cells are strictly aerobic, Gram-stain-negative, non-motile, non-filamentous single rods. Catalase activity is positive (or weakly positive) and cells of some species are negative in tests for oxidase activity. Growth is moderately sensitive to $\mathrm{NaCl}[<2 \%(\mathrm{w} / \mathrm{v})]$. Positive result in tests for gelatin liquefaction, but negative result for urease activity and nitrate reduction. Major cellular fatty acids are iso- $\mathrm{C}_{15: 0}$ and iso- $\mathrm{C}_{17: 0} 3-\mathrm{OH}$. The predominant respiratory quinone is MK-7, with MK-6 as a minor component. The DNA G + C content is $47.0-48.9 \mathrm{~mol} \%$. The type species is Terrimonas ferruginea.

\section{Description of Terrimonas rubra sp. nov.}

Terrimonas rubra (ru'bra. L. fem. adj. rubra red, describing the colour of the cells).

Shows the following characteristics in addition to those given in the genus description above. Cells are non-sporeforming, rod-shaped $(0.4-0.5 \mu \mathrm{m}$ wide and $1.0-2.5 \mu \mathrm{m}$ long) and lack flagella. Flexirubin-type pigments are present. Whole cells are covered by fimbriae (Fig. 2). Colonies are salmon-red, circular $(1.0-2.0 \mathrm{~mm}$ in diameter) with entire edges and convex. Growth occurs at 20-37 ${ }^{\circ} \mathrm{C}$ (optimum, $30{ }^{\circ} \mathrm{C}$ ), at $\mathrm{pH}$ 5.0-10.0 (optimum,

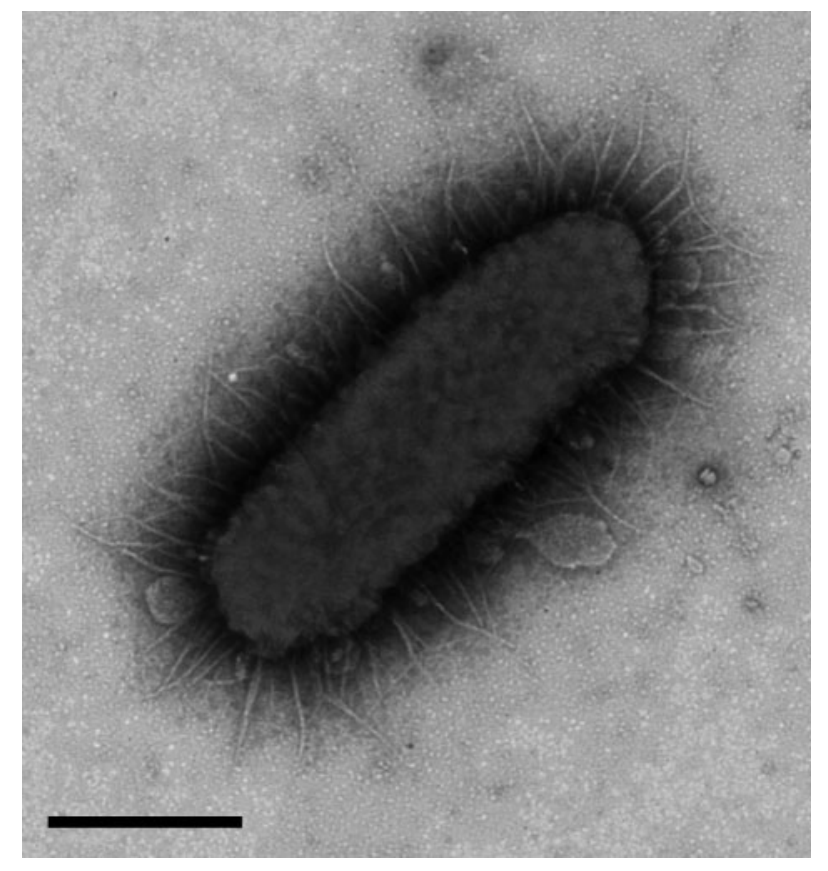

Fig. 2. Transmission electron micrograph of a negatively stained cell of strain $\mathrm{M}-8^{\top}$ grown on R2A agar for $24 \mathrm{~h}$. Bar, $0.5 \mu \mathrm{m}$. 
$\mathrm{pH}$ 7.0) and with $0-2 \%(\mathrm{w} / \mathrm{v}) \mathrm{NaCl}$ (optimum, $0 \%$ ). Positive for catalase activity and negative for oxidase activities. Positive for activities of $\beta$-glucosidase and $\beta$ galactosidase, but negative result for arginine dihydrolase and urease. Hydrolyses gelatin. Negative result in tests for nitrate reduction, indole production and glucose acidification. Assimilates arabinose, glucose, mannose, maltose and $\mathrm{N}$-acetylglucosamine, but not adipate, caprate, citrate, gluconate, phenyl-acetate, mannitol or malate (API 20NE tests). Positive for activities of alkaline phosphatase, C4 esterase, C8 esterase lipase, C14 lipase, leucine arylamidase, valine arylamidase, cystine arylamidase, trypsin, $\alpha$-chymotrypsin, acid phosphatase, naphthol-AS-BI-phosphohydrolase, $\alpha$-galactosidase, $\alpha$-glucosidase, $N$-acetyl- $\beta$-glucosaminidase and $\beta$-fucosidase, but negative result for $\beta$-galactosidase, $\beta$-glucuronidase, $\beta$-glucosidase and $\alpha$-mannosidase activity (API ZYM tests). The following compounds are utilized as sole carbon sources in the GN2 microplate: $\alpha$-cyclodextrin, dextrin, glycogen, Tweens 40 and 80 , L-arabinose, cellobiose, D-fructose, D-galactose, gentiobiose, $\alpha$-D-glucose, maltose, melibiose, turanose, methyl pyruvate, acetic acid, D-galacturonic acid, $\beta$-hydroxybutyric acid, DL-lactic acid, propionic acid, succinic acid and glycyl-L-glutamic acid. The other substrates in the GN2 microplate are not utilized. Susceptible to chloramphenicol, rifampicin, vancomycin, novobiocin, tetracycline, roxithromycin and nalidixic acid, but resistant to gentamicin, streptomycin, kanamycin, ampicillin, spectinomycin, penicillin $G$ and trimethoprim. The major fatty acids are iso- $\mathrm{C}_{15: 0}$, iso- $\mathrm{C}_{17: 0} 3-\mathrm{OH}$ and summed feature 3 (comprising $\mathrm{C}_{16: 1} \omega 7 c$ and/or $\mathrm{C}_{16: 1} \omega 6 c$ ). The predominant respiratory quinone is MK-7.

The type strain, $\mathrm{M}-8^{\mathrm{T}}\left(=\mathrm{CCTCC}\right.$ AB $2010401^{\mathrm{T}}=\mathrm{KCTC}$ $23299^{\mathrm{T}}$ ), was isolated from a polluted farmland soil sample in Shandong Province, China. The DNA G + C content of the type strain is $47.0 \mathrm{~mol} \%$ (HPLC).

\section{Acknowledgements}

This work was supported by the National Natural Science Foundation of China (grants 30900044, 31000001) and Fund for the Doctoral Program of Higher Education (20090097120031).

\section{References}

Beveridge, T. J., Lawrence, J. R. \& Murray, R. G. E. (2007). Sampling and staining for light microscopy. In Methods for General and Molecular Microbiology, 3rd edn, pp. 19-33. Edited by C. A. Reddy, T. J. Beveridge, J. A. Breznak, G. A. Marzluf, T. M. Schmidt \& R. L. Snyder. Washington, DC: American Society for Microbiology.

Chung, Y. C., Kobayashi, T., Kanai, H., Akiba, T. \& Kudo, T. (1995). Purification and properties of extracellular amylase from the hyperthermophilic archaeon Thermococccus profundus DT5432. Appl Environ Microbiol 61, 1502-1506.
Collins, M. D. (1985). Isoprenoid quinone analysis in classification and identification. In Chemical Methods in Bacterial Systematics, pp. 267287. Edited by M. Goodfellow \& D. E. Minnikin. London: Academic Press.

Ezaki, T., Hashimoto, Y. \& Yabuuchi, E. (1989). Fluorometric deoxyribonucleic acid-deoxyribonucleic acid hybridization in microdilution wells as an alternative to membrane filter hybridization in which radioisotopes are used to determine genetic relatedness among bacterial strains. Int J Syst Bacteriol 39, 224-229.

Fautz, E. \& Reichenbach, H. (1980). A simple test for flexirubin type pigments. FEMS Microbiol Lett 8, 87-91.

Felsenstein, J. (1985). Confidence limits on phylogenies: an approach using the bootstrap. Evolution 39, 783-791.

Kimura, M. (1980). A simple method for estimating evolutionary rates of base substitutions through comparative studies of nucleotide sequences. J Mol Evol 16, 111-120.

Kimura, M. (1983). The Neutral Theory of Molecular Evolution. Cambridge: Cambridge University Press.

Lane, D. J. (1991). 16S/23S rRNA sequencing. In Nucleic Acid Techniques in Bacterial Systematics, pp. 115-175. Edited by E. Stackebrandt \& M. Goodfellow. Chichester: Wiley.

Li, W. J., Xu, P., Schumann, P., Zhang, Y. Q., Pukall, R., Xu, L. H., Stackebrandt, E. \& Jiang, C. L. (2007). Georgenia ruanii sp. nov., a novel actinobacterium isolated from forest soil in Yunnan (China), and emended description of the genus Georgenia. Int J Syst Evol Microbiol 57, 1424-1428.

Marmur, J. (1961). A procedure for the isolation of deoxyribonucleic acid from micro-organisms. J Mol Biol 3, 208-218.

Mesbah, M., Premachandran, U. \& Whitman, W. B. (1989). Precise measurement of the $\mathrm{G}+\mathrm{C}$ content of deoxyribonucleic acid by high-performance liquid chromatography. Int J Syst Bacteriol 39, 159-167.

Sasser, M. (1990). Identification of bacteria by gas chromatography of cellular fatty acids. USFCC Newsl 20, 16.

Sheu, S. Y., Cho, N. T., Arun, A. B. \& Chen, W. M. (2010). Terrimonas aquatica sp. nov., isolated from a freshwater spring. Int J Syst Evol Microbiol 60, 2705-2709.

Stackebrandt, E. \& Goebel, B. M. (1994). Taxonomic note: a place for DNA-DNA reassociation and $16 \mathrm{~S}$ rRNA sequence analysis in the present species definition in bacteriology. Int J Syst Bacteriol 44, 846849.

Tamura, K., Dudley, J., Nei, M. \& Kumar, S. (2007). MEGA4: molecular evolutionary genetics analysis (MEGA) software version 4.0. Mol Biol Evol 24, 1596-1599.

Thompson, J. D., Gibson, T. J., Plewniak, F., Jeanmougin, F. \& Higgins, D. G. (1997). The CLUSTAL_X windows interface: flexible strategies for multiple sequence alignment aided by quality analysis tools. Nucleic Acids Res 25, 4876-4882.

Xie, C. H. \& Yokota, A. (2006). Reclassification of [Flavobacterium] ferrugineum as Terrimonas ferruginea gen. nov., comb. nov., and description of Terrimonas lutea sp. nov., isolated from soil. Int J Syst Evol Microbiol 56, 1117-1121.

Zhou, Y., Dong, J., Wang, X., Huang, X., Zhang, K. Y., Zhang, Y. Q., Guo, Y. F., Lai, R. \& Li, W. J. (2007). Chryseobacterium flavum sp. nov., isolated from polluted soil. Int J Syst Evol Microbiol 57, 1765-1769. 